\title{
Status of Marine Turtles in British Columbia Waters: A Reassessment
}

\author{
Donald F. McAlpine ${ }^{1}$, Stan A. Orchard ${ }^{2,5}$, Kelly A. Sendall $^{3}$, and Rod Palm ${ }^{4}$ \\ ${ }^{1}$ New Brunswick Museum, 277 Douglas Avenue, Saint John, New Brunswick E2K 1E5 Canada dmcalpin@nb.aibn.com \\ ${ }^{2,3}$ Royal British Columbia Museum, 675 Belleville Street, Victoria, British Columbia V8W 9W2 Canada \\ ${ }^{4}$ Strawberry Isle Research Society, Box 213, Tofino, British Columbia VOR 2Z0 Canada \\ ${ }^{5}$ Present address: World Wide Fund for Nature, GPO Box 528, Sydney, NSW 2001 Australia
}

McAlpine, Donald F., Stan A. Orchard, Kelly A. Sendall, and Rod Palm. 2004. Status of marine turtles in British Columbia waters: a reassessment. Canadian Field-Naturalist 118(1): 72-76.

Marine turtles in British Columbia have previously been considered off course stragglers. Here we document 20 new reports for Green Turtles, Chelonia mydas, and Leatherback Turtles, Dermochelys coriacea, for the province. Until recently there had been no concerted effort to acquire data on marine turtle abundance or frequency off British Columbia. Observations presented here allow a reassessment of marine turtle status in British Columbia waters. We suggest Green Turtles and Leatherbacks should be considered rare vagrants and uncommon seasonal residents, respectively, off British Columbia and that they are a natural part of the British Columbia marine environment.

Key Words: Green Turtle, Chelonia mydas, Leatherback Turtle, Dermochelys coriacea, British Columbia, status.

There are few published reports for marine turtles in British Columbia waters. Marine turtles in the province have generally been considered "straggler[s]" (Kermode 1932) or "off course" (Gregory and Campbell 1984). Nussbaum et al. (1983) ignore marine turtles in their treatment of northwest amphibians and reptiles, and marine turtles are not included in a recent field guide to northwest reptiles "because sea turtles rarely visit these shores" (St. John 2002). During the preparation of a review of the status and conservation of marine turtles in Canadian waters (McAlpine et al. in press) recent occurrences of Green Turtles off British Columbia were encountered (McAlpine et al. 2002). Here we document additional new reports for Green Turtles, Chelonia mydas, as well as Leatherback Turtles, Dermochelys coriacea, for British Columbia. These new records nearly double the number of published occurrences for marine turtles from the province. When considered in the context of a recent compilation for adjacent Alaska (Hodge and Wing 2000), these observations suggest a reassessment of sea turtle status in British Columbia waters is warranted. The precipitous decline in Pacific Leatherback numbers (Spotila et al. 2000), so serious it has led to a call for a moratorium on long-line fishing in the Pacific Ocean (Anonymous 2002), also provides a timely context.

Based on terms used to document bird status in Alaska, Wing and Hodge (2002) have proposed a standardized terminology to describe marine turtle occurrences. This terminology, ranging through seven categories from accidental to abundant, is loosely based on number of occurrences only. Although useful, this system ignores the ecological context for occurrence. Here we suggest modifying the system of Wing and Hodge (2002) by adding, where appropriate, one of four descriptors to their categories: resident, seasonal resident, migrant, or vagrant. Resident refers to turtles present year round, seasonal resident refers to turtles present only at certain times of the year, migrant refers to turtles moving through a broad area to another location, vagrant refers to turtles occurring outside their normal resident or migratory range. We use this system, in conjunction with that of Wing and Hodge (2002), to describe marine turtle status in British Columbia.

There are 11 published reports for Green Turtles (Carl 1955; Radovich 1961 cited in Stinson 1984; Hodge and Wing 2000; McAlpine et al. 2002) from British Columbia and 14 reports of Leatherbacks (Kermode 1932; Carl, 1944, 1960; MacAskie and Forester 1962). Published and unpublished marine turtle reports for British Columbia prior to 1982 are summarized in Stinson (1984). Table 1 lists one unpublished British Columbia Green Turtle report, included by Stinson (1984) and six new ones; three unpublished Leatherback reports included in Stinson (1984) and 10 new Leatherback occurrences. There are currently 26 British Columbia reports for the Leatherback accompanied by sufficient locality data to map (McAlpine et al. in press), as well as other reports which are not site-specific. All of the 16 British Columbia Green Turtle reports can be map plotted (McAlpine et al. 2003). Several of the recent Green Turtle records are supported by photographic evidence (Figures 13 ), as are four of the Leatherback sightings (Figure 4; Table 1). The skull in Figure 1 is readily identified as that of C. mydas using the figures in Wyneken (2001). This stranding is reported in issue Number 2 of $K S M$ Wutsiin, the official newletter of Hartley Bay School. Unfortunately, the skeletal remains of this turtle were not retained. Detailed necropsies carried out on the Green Point and Matlahaw Point C. mydas are now archived at the Royal British Columbia Provincial 
TABLE 1. Recent occurrences of marine turtles from British Columbia waters.

\begin{tabular}{|c|c|c|c|c|}
\hline Date & Location & Latitude(N) & Longitude $(\mathrm{W})$ & Comments \\
\hline \multicolumn{5}{|l|}{ Chelonia mydas } \\
\hline 22 November 1996 & Hartley Bay & $53^{\circ} 25^{\prime}$ & $129^{\circ} 15^{\prime}$ & Carcass, Figure 1 \\
\hline early November 1998 & mouth of Tlell R & $53^{\circ} 36^{\prime}$ & $131^{\circ} 56^{\prime}$ & Carcass, $\mathrm{PC}^{1}$ : W. Flood to DFM \\
\hline early November 1998 & $5 \mathrm{~km} \mathrm{~S}$ of Tlell R & $53^{\circ} 35^{\prime}$ & $131^{\circ} 54^{\prime}$ & Carcass, PC: W. Flood to DFM \\
\hline 6 November 2001 & $4 \mathrm{~km} \mathrm{~N}$ of Tlell $\mathrm{R}$ & $53^{\circ} 37^{\prime}$ & $131^{\circ} 55^{\prime}$ & Fresh carcass, carapace $78.7 \mathrm{~cm}$, Figure 2 \\
\hline 20 December 2001 & Greene Point & $49^{\circ} 03^{\prime}$ & $125^{\circ} 43^{\prime}$ & Fresh carcass, male, carapace $68.7 \mathrm{~cm}$, Figure 3 \\
\hline 21 January 2002 & Matlahaw Point & $49^{\circ} 23^{\prime}$ & $126^{\circ} 29^{\prime}$ & Carcass, male, carapace $69.9 \mathrm{~cm}$ \\
\hline \multicolumn{5}{|l|}{ Dermochelys coriacea } \\
\hline mid-July 1970 & Shart & $51^{\circ} 30^{\prime}$ & $128^{\circ} 45^{\prime}$ & Stins \\
\hline summer 1977 & Off Ucluelet & $49^{\circ} 55^{\prime}$ & $126^{\circ} 38^{\prime}$ & Stinson (1984) \\
\hline September 1977 & Off Ucluelet & $49^{\circ} 00^{\prime}$ & $125^{\circ} 50^{\prime}$ & Free swimming, RBCPM photo number 695 \\
\hline 30 August 1981 & Skidijate Inlet & $53^{\circ} 15^{\prime}$ & $131^{\circ} 57^{\prime} 30^{\prime \prime}$ & Alive in salmon gillnet, RBCPM photo number 749 \\
\hline 1 September 1981 & Hectate Strait & $53^{\circ} 20^{\prime}$ & $130^{\circ} 30^{\prime}$ & Stinson (1984) \\
\hline 16 September 1982 & Esperanza Inlet & $49^{\circ} 52^{\prime}$ & $126^{\circ} 44^{\prime}$ & RBCPM photo number 826 \\
\hline August 1993 & Clerke Point & $50^{\circ} 05^{\prime}$ & $127^{\circ} 48^{\prime}$ & Feeding on Cyanea, pc: J. Watson to G. Ellis \\
\hline 26 May 1996 & Mt Douglas Park & $49^{\circ} 08^{\prime}$ & $123^{\circ} 58^{\prime}$ & Free swimming/Times-Colonist, 1 June, page B2 \\
\hline May 1997 & Kyuquot Sound & $50^{\circ} 05^{\prime}$ & $127^{\circ} 13^{\prime}$ & Carcass, PC: G. Jamieson to DFM \\
\hline September 1997 & SE of Langara Island & $54^{\circ} 12^{\prime}$ & $132^{\circ} 58^{\prime}$ & $\begin{array}{l}\text { Free swimming, large numbers of Vellela sp. } \\
\text { present, PC: S. Buchanan to S. Stebbins }\end{array}$ \\
\hline Spring 1998 & Tofino & $49^{\circ} 07^{\prime}$ & $125^{\circ} 53^{\prime}$ & Decomposed carcass, $\mathrm{PC}$ : to $\mathrm{SAO}$ \\
\hline 6 September 2000 & off shore & $48^{\circ} 43^{\prime} 1$ & $127^{\circ} 26^{\prime}$ & Free swimming, PC: K. Morgan to DFM \\
\hline 4 August 2001 & off Langara Island & $54^{\circ} 18^{\prime}$ & $133^{\circ} 10^{\prime}$ & Free swimming, PC: E. Simkin to G. Ellis, Figure 4 \\
\hline
\end{tabular}

${ }^{1} \mathrm{PC}=$ personal communication.

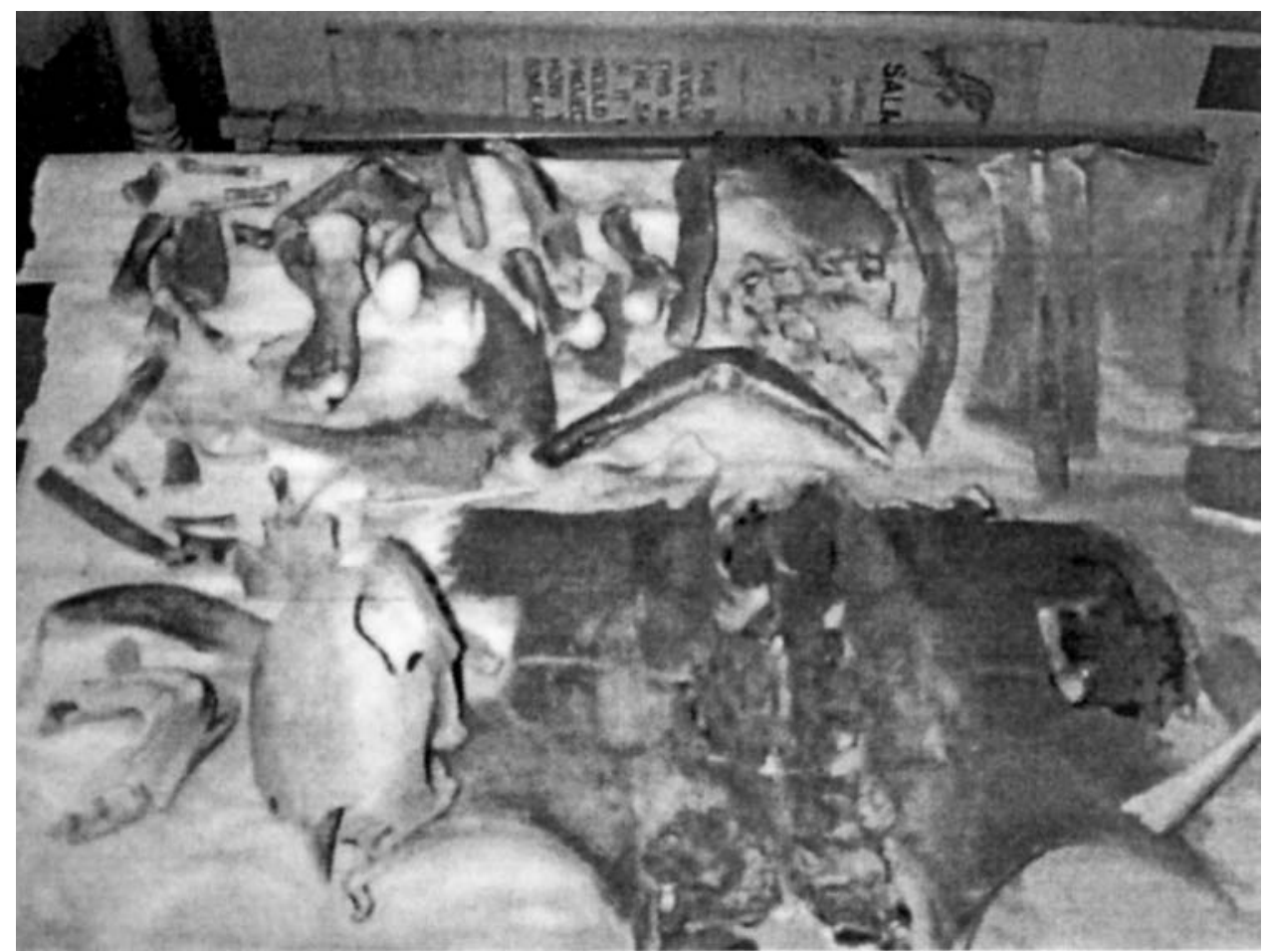

FIGURE 1. Skeletal remains of a dead Green Turtle stranded at Hartley Bay, British Columbia, 22 November 1996. The skull in this photo can be readily identified as that of C. mydas (Hartley Bay School photo). 
Museum and the Strawberry Isle Research Society, Tofino. A report prepared by a veterinary pathologist following examination of the Green Point Turtle states this turtle died from a bacterial infection to which it may have been predisposed following exposure to environmental stressors, such as low water temperature. The animal was also suffering from a moderately severe case of pneumonia. The Matlahaw turtle appeared healthy and cause of death was not determined.

Gregory and Campbell (1984) suggested the single live Green Turtle from British Columbia reported by Carl (1955) was "probably just off course". On the basis of minimum thermal tolerance in cheloniid turtles and the few additional reports of live C. mydas. McAlpine et al. (2002) concurred, considering the species "accidental" in the province. Kermode (1932) identified the Leatherback as a "straggler" in the North Pacific, Carl (1944) reported the species as "wandering" to British Columbia waters, and Cook $(1981 *)$ considered Leatherback Turtles observed in Canada were either "migrants or strays".

Stinson (1984), however, suggested occurrences of sea turtles in the northeastern Pacific could not be dismissed as accidental but are influenced by temperature anomalies in the ocean. While she found sightings of marine turtles occur regularly during years of normal ocean temperatures, greater numbers of turtles were observed than expected when sea temperatures were above the mean. Hodge and Wing (2002) noted that in Alaska marine turtle occurrences are almost equally divided between warm-water and normal-water years. Most noteworthy was the complete lack of turtles in cold-water years.

Whether the increased number of recent reports reflects a real increase in the prevalence of marine turtles off British Columbia, or simply increased public awareness and reporting, is unknown. However, based on their standardized occurrence terminology for
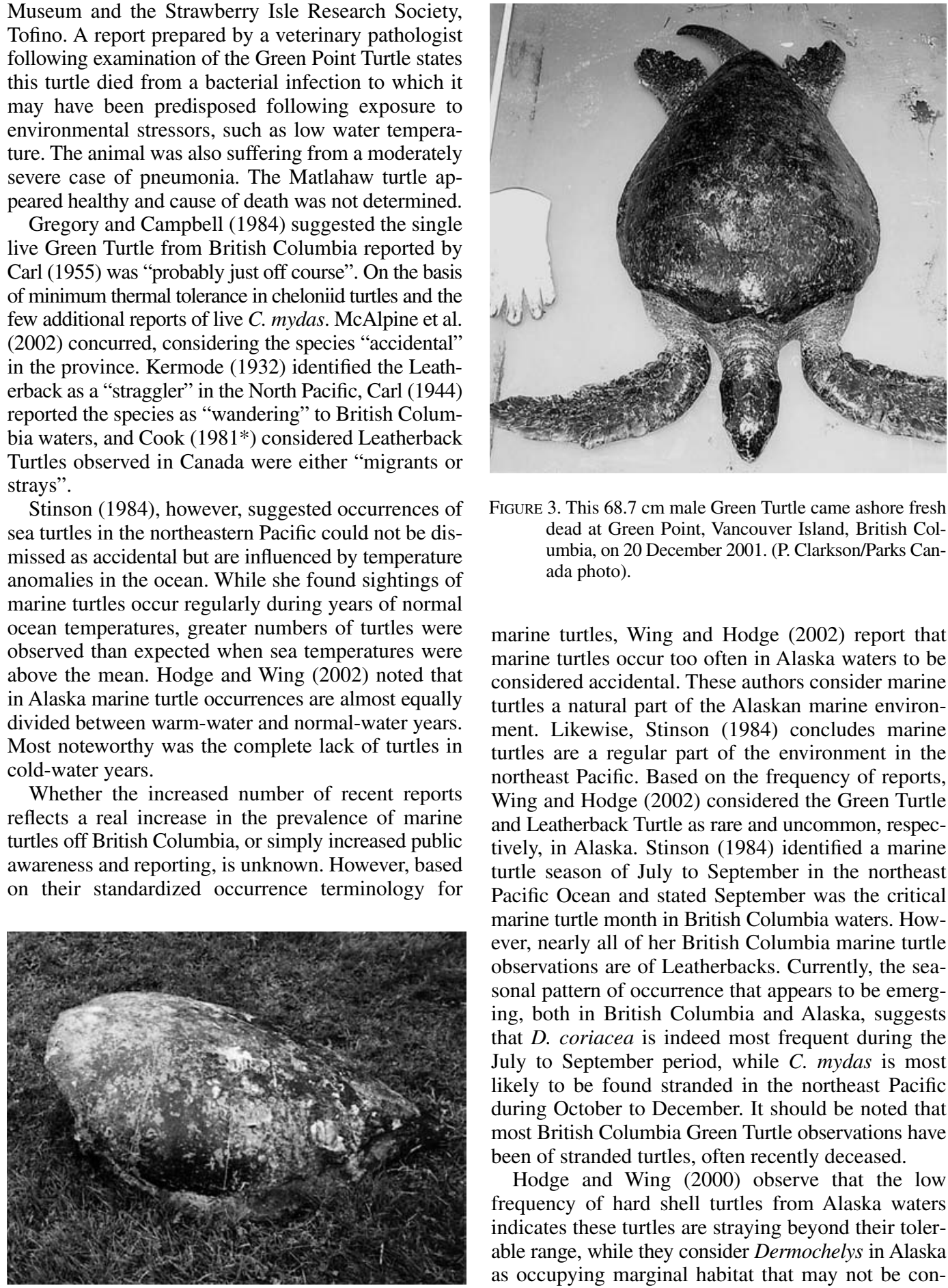

FIGURE 3. This $68.7 \mathrm{~cm}$ male Green Turtle came ashore fresh dead at Green Point, Vancouver Island, British Columbia, on 20 December 2001. (P. Clarkson/Parks Canada photo).

marine turtles, Wing and Hodge (2002) report that marine turtles occur too often in Alaska waters to be considered accidental. These authors consider marine turtles a natural part of the Alaskan marine environment. Likewise, Stinson (1984) concludes marine turtles are a regular part of the environment in the northeast Pacific. Based on the frequency of reports, Wing and Hodge (2002) considered the Green Turtle and Leatherback Turtle as rare and uncommon, respectively, in Alaska. Stinson (1984) identified a marine turtle season of July to September in the northeast Pacific Ocean and stated September was the critical marine turtle month in British Columbia waters. However, nearly all of her British Columbia marine turtle observations are of Leatherbacks. Currently, the seasonal pattern of occurrence that appears to be emerging, both in British Columbia and Alaska, suggests that $D$. coriacea is indeed most frequent during the July to September period, while C. mydas is most likely to be found stranded in the northeast Pacific during October to December. It should be noted that most British Columbia Green Turtle observations have been of stranded turtles, often recently deceased.

Hodge and Wing (2000) observe that the low frequency of hard shell turtles from Alaska waters indicates these turtles are straying beyond their tolerable range, while they consider Dermochelys in Alaska as occupying marginal habitat that may not be consistently used from year to year. The accumulating number of marine turtle observations from British Columbia suggests that these species are even more

frequent in British Columbia than Alaska. Following dead on 6 November 2001, $4 \mathrm{~km} \mathrm{~N}$ of the Tlell River, Queen Charlotte Islands, British Columbia (V. Flood photo). 


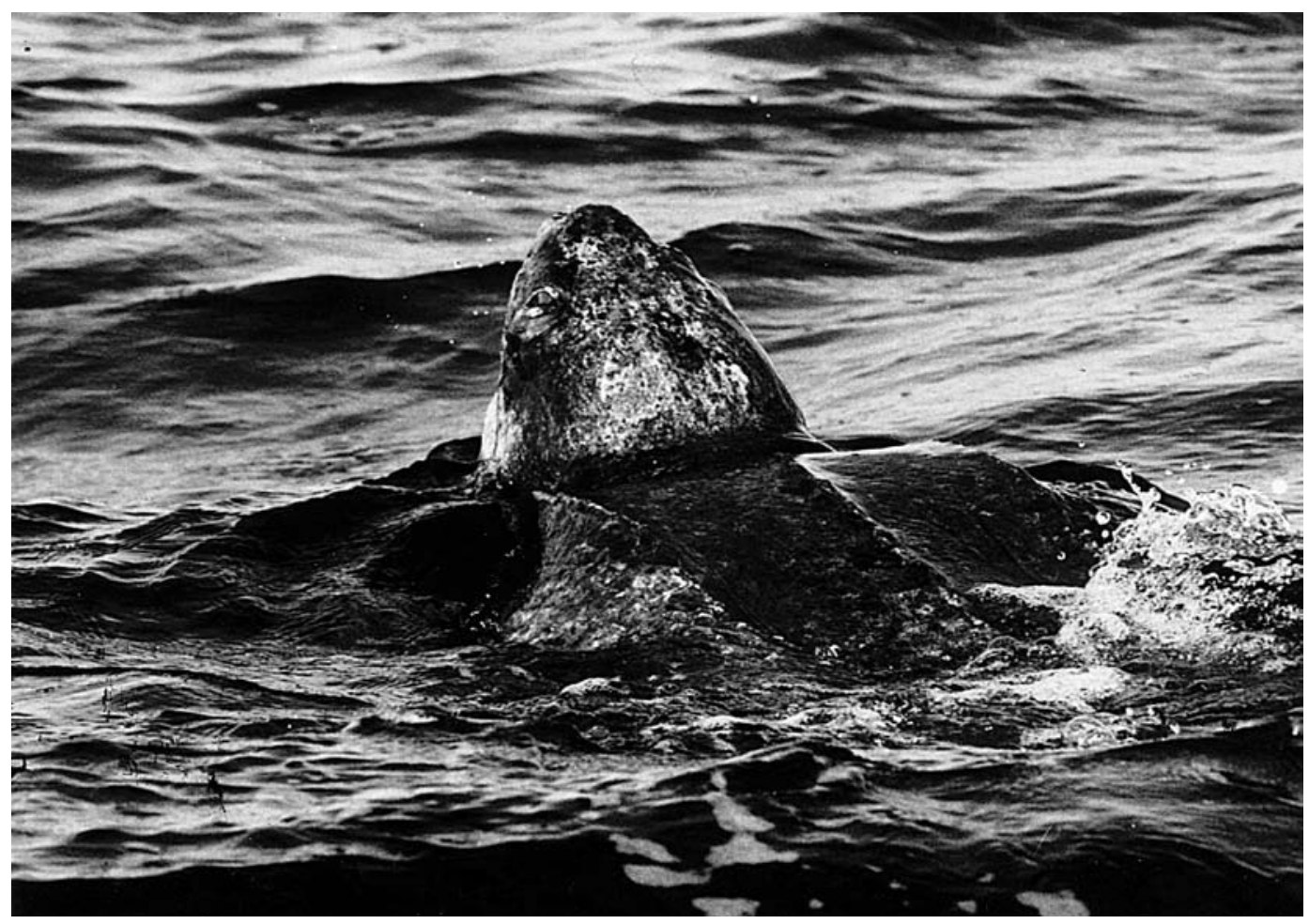

FIGURE 4. Leatherback turtle photographed 4 August 2001 off Langara Island, Queen Charlotte Islands, British Columbia (Erik Simkin photo).

Wing and Hodge (2002), and our own suggestions above, we describe $C$. mydas as a rare vagrant and and $D$. coriacea as an uncommon seasonal resident in British Columbia waters. However, we would add there has been no effort to methodically collect information from dead stranded turtles nor, until a recent initiative by the Vancouver Aquarium (C. Sbrocchi, personal communication to DFM), to acquire sightings data on marine turtle abundance or frequency off British Columbia. Anecdotal information on several Leatherback occurrences is included in the $K S M$ Wutsiin newsletter noted above, indicating canvassing local communities, and especially native fishers, could be a source of information on marine turtle occurrences in British Columbia. Additionally, Glen Jamieson (Pacific Biological Station, personal communication to DFM) reports that Leatherbacks are "periodically seen off the west coast of [Vancouver Island]" and Frank Bernard (Pacific Biological Station, personal communication to $\mathrm{SAO}$ ) reported that he had seen as many as six Leatherbacks in a day $80-320 \mathrm{~km}$ off the west coast of Vancouver Island. Reports of the Pacific Ridley, Lepidochelys olivacea, and the Loggerhead, Caretta caretta, for Alaska (Hodge and Wing 2000) suggest focused investigations may reveal these species also occur off the British Columbia coast.

\section{Acknowledgments}

We thank the following individuals for sharing British Columbia marine turtle observations and information with us and allowing us to include their reports here: Scott Buchanan, Barry Campbell, Graeme Ellis, Glen Jamieson, Marilyn Joyce, Wayne and Virginia Flood, Ken Morgan, Carla Sbrocchi, Eric Simkin, Jane Watson, Kris Willcock, and the late Frank Bernard. In particular, we would like to thank Eric Hill and Simone Westgarth of the Hartley Bay School for their efforts in obtaining information that allowed identification of the Hartley Bay turtle.

\section{Documents Cited (marked * in text)}

Cook F. R. 1981. Status report on the Leatherback Turtle, Dermochelys coriacea. Committee on the Status of Endangered Wildlife in Canada, Ottawa, 17 pages.

\section{Literature Cited}

Anonymous. 2002. Moratorium on Pacific long-lining could save leatherbacks. Marine Turtle Newsletter 97: 26.

Carl, G. C. 1944. The reptiles of British Columbia. Handbook Number 3. British Columbia Provincial Museum, Victoria, British Columbia.

Carl, G. C. 1955. The green turtle in British Columbia. Report of the Provincial Museum of Natural History and Anthropology, Victoria, British Columbia 1954: B77-78. 
Carl, G. C. 1960. The reptiles of British Columbia. Handbook Number 3. British Columbia Provincial Museum, Victoria, British Columbia.

Gregory, P. T., and R. W. Campbell. 1984. The reptiles of British Columbia. Handbook number 44. British Columbia Provincial Museum, Victoria, British Columbia.

Hodge, R. P., and B. L. Wing. 2000. Occurrences of marine turtles in Alaska waters 1960-1998. Herpetological Review 31: 148-151.

Kermode, F. 1932. A remarkable capture of Leatherback Turtles off Bajo Reef, near Nootka Sound, West Coast of Vancouver Island, British Columbia. Report of the Provincial Museum of Natural History for the year 1931. Victoria, B.C. Pages 6-7.

MacAskie, I. B., and C. R. Forrester. 1962. Pacific Leatherback off the coast of British Columbia. Copeia 1962: 646.

McAlpine, D. F., M. C. James, J. Lien, and S. A. Orchard. In press, Status and conservation of marine turtles in Canadian waters. In Ecology, conservation and status of reptiles in Canada. Edited by C. R. Seburn and C. A. Bishop. Herpetological Conservation 3.

McAlpine, D. F., S. A. Orchard, and K. A. Sendall. 2002. Recent occurrences of the green turtle from British Columbia waters. Northwest Science 76: 185-188.
Nussbaum, R. A., E. D. Brodie Jr., and R. M. Storm. 1983. Amphibians and reptiles of the Pacific Northwest. University of Idaho Press, Moscow, Idaho.

Radovich, J. 1961. Relationship of some marine organisms of the northeast Pacific to water temperatures, particularly during 1957 through 1959. California Fish and Game, Fisheries Bulletin 112: 1-62.

Spotila, J. R., R. D. Reina, A. C. Steyermark, P. T. Plotkin, and F. V. Paladino. 2000. Pacific Leatherback Turtles face extinction. Nature 405: 529-530.

Stinson, M. L. 1984. Biology of sea turtles in San Diego Bay, California and in the northeastern Pacific Ocean. MSc. thesis, San Diego State University, California.

St. John, A. 2002. Reptiles of the Northwest: British Columbia to California. Lone Pine Publishing, Edmonton, Alberta.

Wing, B. L., and R. P. Hodge. 2002. Occurrence terminology for marine turtles. Marine Turtle Newsletter 95: 15-16.

Wyneken, J. 2001. The anatomy of sea turtles. U.S. Department of Commerce, NOAA Technical Memorandum NMFS-SEFSC-470. 172 pages.

Received 27 February 2003

Accepted 20 November 2003 